Teologia i Moralność, volumen 16(2021), numer 2(30)

doi: 10.14746/TIM.2021.30.2.14

ORCID: 0000-0001-5266-9388

DAWID STELMACH

Uniwersytet im. Adama Mickiewicza w Poznaniu

Wydział Teologiczny

\title{
Rola duchowieństwa Kościoła rzymskokatolickiego w czasie ludobójstwa w Rwandzie w 1994 roku. Spojrzenie z perspektywy 27 lat po wydarzeniach
}

\section{Wstęp}

Ludobójstwo w Rwandzie w 1994 r. dokonane przez przedstawicieli plemienia Hutu na przedstawicielach plemienia Tutsi stało się jedną z najciemniejszych kart światowej historii końca dwudziestego wieku. Stosunkowo niewielka - wtedy około sześciomilionowa - Rwanda znalazła się nagle w centrum zainteresowania całego świata. Począwszy od środy wielkanocnej 6 kwietnia 1994 r. przez sto kolejnych dni zginęło - według różnych szacunków - od ośmiuset tysięcy do miliona mieszkańców Rwandy. Nie był to pierwszy krwawy konflikt w dziejach Rwandy. Jak historia pokazała, ten konflikt jednak odcisnął szczególnie mocne piętno na tym niewielkim kraju w rejonie wielkich jezior Afryki. Jednocześnie Rwanda stała się też znana na całym świecie, a nazwy plemion Hutu i Tutsi weszły już na trwałe do historii świata. Celem tego przedłożenia jest pokazanie, jak w kontekście ludobójstwa 1994 r. zachowywało się duchowieństwo Kościoła rzymskokatolickiego. Po 27 latach od tych tragicznych wydarzeń nadal rola i zachowanie duchownych w Rwandzie nie są w pełni ukazane. Niech poniższe opracowanie pomoże pokazać tę rolę i zachowania w szerszej perspektywie.

\section{Duchowieństwo Kościoła przed ludobójstwem}

Rwanda znalazła się w optyce zainteresowania Kościoła rzymskokatolickiego od początku dwudziestego wieku. Pierwsza delegacja misjonarzy spotkała się 
z królem Rwandy w Nyanzie 2 lutego 1900 r. Kilka dni później rozpoczęto pierwszą ewangelizację, a w 1903 r. ochrzczono pierwszą grupę katechumenów (Jaworski 2020,24). Oto ten kraj stał się swoistym przykładem modelowo przebiegającej ewangelizacji w Afryce. Zgromadzenia misyjne zakładały nowe placówki i stacje wraz z podstawowym szkolnictwem, poprzez szkolnictwo zawodowe aż po katolicki uniwersytet. Począwszy od 1900 r. Rwanda stała się przykładem kraju, gdzie ewangelizacja nieustannie się rozwijała. Zaczęto tworzyć nowe struktury Kościoła: wikariaty apostolskie, diecezje, archidiecezja z własną metropolią w Kigali. Pojawiły się rodzime powołania kapłańskie i zakonne. Niektóre zgromadzenia, jak np. oo. Biali, ze względu na swój charyzmat nie przyjmowały rodzimych powołań, ale bezpośrednio kierowały je do lokalnych seminariów diecezjalnych. Dzięki temu zabiegowi od początku budowano struktury miejscowego Kościoła diecezjalnego. Pierwszy własny wikariat apostolski powstaje dla Ruandy w 1922 r., ze stolicą w Kabgayi (Diocese of Kabgayi, 2021). Oprócz zgromadzeń typowo misyjnych, z czasem pojawiły się także zakony, które w zasadzie nie miały misyjnego charyzmatu. W latach siedemdziesiątych do Rwandy przybyły grupy pierwszych polskich misjonarzy ze Stowarzyszenia Apostolstwa Katolickiego - Pallotyni (1973) oraz później Karmelici Bosi (1984). Obydwa zgromadzenia zakonne w znaczny sposób przyczyniły się do rozwoju lokalnego Kościoła. Nastąpiło bowiem budowanie nowych parafii, tworzenie nowych miejsc kultu (sanktuariów), powstanie drukarni katolickiej w Kigali, tworzenie lokalnych domów formacyjnych. Swoistym fenomenem było własne duszpasterstwo rodzin opracowane przez księdza Henryka Hosera SAC. Ksiądz Hoser, z zawodu lekarz, chciał zaproponować autorską metodę adaptacji naturalnego planowania rodziny do warunków afrykańskich. W miejscowej kulturze, gdzie bardzo mocno dominuje resentyment pokolonizacyjny, lokalne ludy nieustannie mają poczucie krzywdy i wykorzystania od czasów kolonialnych. Przekłada się to na niemal systemową nieufność wobec propozycji, jakie przynoszą ludzie zachodu (biali). O ile zdobycze cywilizacyjne - takie jak: łączność telekomunikacyjna, rozwiązania infrastrukturalne, budowa dróg, transport samochodowy i autobusowy - nie budzą zastrzeżeń i są ochoczo przyjmowane jako pewnego rodzaju wprowadzenie w krąg cywilizacji technologicznej, o tyle rozwiązania dotyczące kontrolowania ludzkiego rozrodu, ograniczenie liczby potomstwa i uzależnienie od tego pomocy międzynarodowej nie są dla nich do zaakceptowania. Rdzenni Afrykańczycy znacznie chętniej decydowali się na większą liczbę dzieci, które miały zapewnić im w przyszłości bezpieczny byt. Ksiądz Henryk Hoser SAC w swoim modelu duszpasterstwa rodzin z jednej strony postanowił uwzględnić rdzenne tradycje i poszanowanie dla posiadania dużej liczby dzieci, a $\mathrm{z}$ drugiej strony chciał też pomóc w otwarciu się na nowoczesne metody rozpoznawania płodności. Ten autorski model księdza Hosera stał się dość popularny w duszpasterstwie rodzin w Rwandzie i zapewnił mu też lokalną rozpoznawalność. Rwandyjska Akcja Rodzinna miała swych przed- 
stawicieli w każdej diecezji kraju, a dokładniej w osiemdziesięciu parafiach, a jej twórca - ksiądz Henryk Hoser SAC - został jej dyrektorem z ramienia Episkopatu (Hoser i Królikowski 2013, 21).

Wraz z przyjściem Kościoła rzymskokatolickiego do Rwandy rozpoczęło się rozwijanie katolickiego szkolnictwa w tym kraju. Obecnie średni zarobek Rwandyjczyka na prowincji waha się $\mathrm{w}$ okolicach $50 €$ za miesiąc pracy, natomiast w stolicy, w Kigali jest to około $200 €$ miesięcznie. Porównując to z warunkami krajów zachodnich, bardzo łatwo zrozumieć, że nie jest to kraj bogaty, a wręcz ubogi. Obecnie większość domów na wsi nie posiada ani elektryczności, ani dostępu do wody. Zazwyczaj jest to bądź jedna studnia, bądź źródło w centrum wsi, a w miastach są po prostu punkty dostępu do wody, gdzie ludzie w kolejce z baniakami napełniają swoje pojemniki i potem je przynoszą do domu, niekiedy pokonując po kilka kilometrów. W tych realiach wykształcenie dzieci bywa często potrzebą, która nie jest pierwszorzędną. Działania Kościoła rzymskokatolickiego skupiło się między innymi na tym, aby zachęcić Rwandyjczyków do kształcenia swoich dzieci. Zazwyczaj z piątki dzieci w jednej rodzinie może kształcić się jedno bądź dwoje. Nauka jest płatna, na miarę lokalnych zarobków, do $10 €$ miesięcznie. Ta opłata nie pokrywa pełnego zapotrzebowania na utrzymanie uczniów i nauczycieli, ale jest udziałem rodziców w tych kosztach. Katolickie szkolnictwo w Rwandzie to około 50\% szkół podstawowych, jakie działają w tym kraju. Przez około 120 lat Kościół rzymskokatolicki - także przez swoich duchownych - zbudował sprawnie działającą sieć szkolnictwa, która skutecznie ogranicza poziom analfabetyzmu w społeczeństwie. Szkolnictwo katolickie jest obecne na każdym poziomie - także jako szkoły zawodowe czy na poziomie akademickim - Katolicki Uniwersytet Rwandy z siedzibą w Butare (od 2006 r. nowa nazwa Huye, która nawiązuje do lokalnych tradycji) (Rwanda Convention Bureau, 2021).

To wszystko oddziaływało nie tylko na umocnienie ewangelizacji, ale było rozwinięciem i pogłębieniem pracy formacyjnej. $Z$ jednej strony zrodzenie nowych powołań kapłańskich i zakonnych odczytywano jako wyraz dojrzałości lokalnego Kościoła. Z drugiej strony trudno było zweryfikować, czy te powołania są dostatecznie dojrzałe, aby powiedzieć, że w chwili próby zwycięży ewangelia nad przynależnością plemienną. Odpowiedź na to pytanie, którego sobie wtedy nie zadawano, nadeszła z całą mocą podczas ludobójstwa w 1994 r.

\section{Postawa duchowieństwa w trakcie stu dni ludobójstwa}

Postawy duchowieństwa rzymskokatolickiego w czasie stu dni ludobójstwa do dzisiaj pozostają pewnego rodzaju nieodkrytą tajemnicą. Najczęściej można usłyszeć relacje reporterskie o pojedynczych przypadkach lokalnych - rdzennych duchownych, którzy współpracowali z oprawcami z plemienia Hutu. Wojciech 
Tochman w swojej książce-reportażu pt. Dzisiaj narysujemy śmierć wspomina księdza, który pozwolił schronić się prześladowanym członkom plemienia Tutsi w kościele w Nyange. Następnie zamknął kościół i powiadomił o tym prześladowców z plemienia Hutu. Gdy nie można było dostać się do wnętrza kościoła, postanowiono przy pomocy buldożera przewrócić wieżę kościelną na budynek kościoła. W ten sposób pogrzebano ukrywających się w środku prześladowanych parafian (Tochman 2010, 112). Jest to przykład niezwykle drastyczny i jednocześnie okrutny. Pokazuje, jak bardzo konflikt między plemionami Hutu i Tutsi osiągnął graniczną wartość - tak bardzo, że ludzie byli zdolni do tak wielkiego okrucieństwa. Zaraz po ludobójstwie zrodziły się pytania: dlaczego ten ksiądz mógł sobie na coś takiego pozwolić? Przecież był księdzem i powinien kierować się wskazaniami i wymaganiami ewangelii. Pewne światło na to tragiczne zachowanie księdza rzuca komentarz księdza Jana Pałygi SAC, który pisze o tym, że „należy pamiętać, że pod sutannami oni wciąż byli Tutsi i Hutu” (Bar 2013, 235). Oznacza to, że przynależność etniczna okazywała się nadal znacznie silniejsza niż owoce ewangelizacji Rwandyjczyków - dotyczyło to także duchownych wywodzących się z plemiona Hutu. Tym razem nienawiść zwyciężyła.

Pozostaje jednak pytanie o skalę tego zjawiska - ile było takich przypadków, gdy ksiądz zamiast stanąć w obronie swoich prześladowanych parafian z plemiona Tutsi, dołączał do prześladowców i zabijał swoich parafian? Podczas moich pobytów w Rwandzie w 2017 i 2018 r., gdy już udało się zdobyć zaufanie lokalnego kleru, zazwyczaj dostawałem odpowiedź, że tych duchownych oprawców było nie więcej niż pięciu. Autor bloga „Konrad jest w Rwandzie” przytacza liczbę 21 katolickich księży, powołując się na rozdział pt. „No safety in the God's Hause. The Attack on The Church" z bliżej nieznanej książki (Konrad jest w Rwandzie, 2009).

Obecnie jednak trudno znaleźć opracowania naukowe, które by jednoznacznie dokumentowały takie przypadki. Dlaczego nadal jest to takie trudne? Ponieważ temat ludobójstwa 1994 r., pomimo już znacznej perspektywy czasowej, nadal jest tematem otwartym i bardzo bolesnym w samej Rwandzie. Nie wolno używać oficjalnie nazw Hutu i Tutsi - dzisiaj wszyscy są tylko Rwandyjczykami. Ten nakaz samego prezydenta ma dopełnić dzieła pojednania i zakończenia waśni etnicznych. Jednak sami Rwandyjczycy doskonale wiedzą, jak różnią się między sobą przedstawiciele tych dwóch plemion - jak kształtuje się ich fizjonomia, czym się różnią ich ciała i jak są zbudowane. Rwandyjczycy już na pierwszy rzut oka są w stanie określić, czy stoi przed nimi przedstawiciel plemienia Hutu, czy też Tutsi.

Brak jednoznacznych naukowych opracowań na temat ilości księży, którzy kolaborowali z oprawcami, powoduje, że w artykułach prasowych i doniesieniach reporterskich dominuje narracja o niemalże powszechnym udziale duchowieństwa w ludobójstwie. Jednak fakty są zupełnie inne. W literaturze naukowej można znaleźć świadectwa o tym, że podczas stu dni ludobójstwa zginęło 
pomiędzy 200 (Fried 2017) a 250 (Bar 2013, 235) duchownych Kościoła rzymskokatolickiego - stanowiło to wtedy około jedną czwartą duchowieństwa całego kraju. Według relacji świadków najczęściej ginęli dlatego, że stawali w obronie prześladowanych. Byli to księża, zakonnicy i zakonnice z obu plemion. Najbardziej obecnie znanym wzorem heroicznej obrony jest przykład siostry zakonnej Felicite Niyitegeka z plemienia Hutu, która dobrowolnie oddała życie w obronie 42 uczennic, którymi się opiekowała jako dyrektorka szkolnego internatu. Siostra Felicite w każdej chwili mogła uratować swoje życie, jednak sama kilkakrotnie potwierdzała, że chce zostać z uczennicami do końca - była świadkiem dekapitacji każdej ze swoich uczennic, a na końcu ją też zastrzelono (d'Amour Dusengumuremyi, 2015).

Pomimo tej rażącej dysproporcji - przynajmniej 200 ofiar ludobójstwa spośród szeregu duchowieństwa Kościoła rzymskokatolickiego a minimum 5 lub 21 księży, którzy kolaborowali z oprawcami - w doniesieniach prasowych i reporterskich dominuje narracja o powszechnym udziale duchowieństwa w ludobójstwie Tutsi w 1994 r. Dziennikarze i reporterzy w tych miejscach, gdzie mogliby jednoznacznie przytoczyć liczby, w zadziwiający sposób zazwyczaj milczą. Przytaczają wtedy jeden bądź dwa przykłady heroicznych księży, którzy uratowali swoich parafian. Jednak milczą na temat skali tego, jak wielu duchowych oddało swoje życie, równocześnie dokładnie opisując przykłady księży kolaborantów. Zadziwiające jest to, że również literatura naukowa podąża tym śladem.

Osobną kategorią duchownych podczas ludobójstwa 1994 r. byli misjonarze, którzy pracowali wtedy w Rwandzie. Rebelianci z plemienia Hutu zazwyczaj obcokrajowcom dawali spokój. Wyjątek stanowią losy pewnych polskich misjonarzy: „Dwaj polscy misjonarze, o. Sylwester Potoczny i Marian Sobczyk, zostali uprowadzeni przez rebeliantów do Ugandy. Przeszli pieszo przez zaminowany teren, a następnie byli przetrzymywani w parafii w Mutorere w Ugandzie. Po dołączeniu kolejnego polskiego uchodźcy br. Zdzisława Strzałki, uciekli do Konga. [...] Powrót do Rwandy okazał się niemożliwy, z czym trudno było pogodzić się o. Sylwestrowi" (Jaworski 2020, 175).

Zazwyczaj polscy duchowni misjonarze nie wiedzieli, co do końca się dzieje. Jak często wspominali mi w osobistych relacjach, przychodzili do nich uzbrojeni rebelianci np. z żądaniem benzyny. Nie wiedzieli, po co to jest, więc dawali rebeliantom, którzy mierzyli do nich z broni palnej. Dopiero po czasie okazywało się, że ta benzyna wcale nie posłużyła do uruchomienia samochodu, ale użyto jej do podpalenia kościoła, w którym chowali się ludzie. Pośród biernych postaw były także postawy heroiczne - jak księdza Stanisława Urbaniaka SAC. Duchowny widząc zbliżających się rebeliantów, wyszedł na wprost nich i trzymając w ręku figurę Matki Bożej Fatimskiej, wzywał ich do zawrócenia - mówił: „to są wasi bracia! nie wolno wam ich zabijać! Na to ci z Interahamwe pchnęli księdza w błoto a resztę wsadzili na ciężarówki. I wywieźli na śmierć. Wiadomo, że nie znaleźli 
wszystkich. Że wielu ukrywało się w parafii w rozmaitych komórkach, zakamarkach, w księżowskich szafach" (Tochman 2010, 107).

W niektórych przypadkach taka postawa misjonarza ratowała życie. Najczęściej jednak rebelianci księdzu misjonarzowi nie robili krzywdy, ale skupiali się na zabijaniu przedstawicieli plemienia Tutsi.

Podsumowując rolę misjonarzy duchownych w Rwandzie, należy stwierdzić, że najczęściej w pierwszym kontakcie z oprawcami misjonarze dbali o swoje bezpieczeństwo - od swoich przełożonych zakonnych i kościelnych często dostawali nakaz opuszczenia swoich placówek. Bywało, że jak ks. Stanisław Urbaniak SAC, zostawali na miejscu i wtedy stawali się niemymi świadkami ludobójstwa. Z perspektywy czasu ich postawa jest przedstawiana w wybiórczy sposób. „Spuścili paliwo. / Podeszli do kaplicy. / Zamknięta od środka. / Wytłukli szyby w oknach. Wlali benzynę. / Patrzyliśmy na ogień. / Nazajutrz brat Piotr wyjechał z Gikondo. Wrócił pod koniec sierpnia. / - W spalonej kaplicy wciąż leżały kości. Pochowaliśmy je. W małym grobie. / Tam. Bez nazwisk. Nie wiemy, jak się nazywali" (Tochman 2010, 107).

Dzisiaj ci misjonarze, naoczni świadkowie ludobójstwa, w większości już z Rwandy wyjechali. Czasami próbowali do niej wrócić, aby pomóc temu krajowi podnieść się z popiołów. Jednak można tych misjonarzy określić jako ludzi, których dotknęła podwójna trauma. Mimo woli stali się świadkami rzezi na swoich parafianach. Następnie po latach zostali uznani za współwinnych tego ludobójstwa. Warto zaznaczyć jeszcze jedną rzecz, że nigdzie zarówno w przekazach dziennikarskich, reporterskich, jak i w opracowaniach naukowych, nie można znaleźć świadectwa o tym, że jakikolwiek misjonarz w Rwandzie wziął czynny udział w ludobójstwie. Zazwyczaj jest to traktowane domyślnie, jednak trudno znaleźć takie zdanie sformułowane expressis verbis.

\section{Kościół i jego duchowni po ludobójstwie}

Sto dni ludobójstwa w Rwandzie oznaczało także zmiany w politycznym kierownictwie państwa. Jak wcześniej u władzy było dominujące liczebnie plemię Hutu - stanowi około 85\% populacji Rwandy - tak po ludobójstwie, pod wpływem zwycięstwa wojsk Patriotycznego Frontu Rwandy (RPF), dokonała się zmiana politycznego kierownictwa. Władze w kraju przejęła partia RPF, która była kontynuacją wojsk o tej samej nazwie. Tej formacji wojskowej przewodził Paul Kagame, a jej wkroczenie do Rwandy w lipcu 1994 r. położyło kres rzezi Tutsi. Najpierw prezydentem został Pasteur Bizimungu (Reginia-Zacharski 2012, 222), a w roku 2000 jego miejsce zajął dotychczasowy wiceprezydent Paul Kagame i tę władzę nieprzerwanie sprawuje aż do teraz, to jest $2021 \mathrm{r}$. W kulturze politycznej 
Rwandy dominuje obecnie autokracja monopartyjna, a prezydent jest wybierany na kolejne siedmioletnie kadencje z poparciem pomiędzy 93 a 98\%.

Gdy przyszedł czas rozliczeń po ludobójstwie, duchowieństwo rzymskokatolickie stało się jednym z tych środowisk, wobec którego wysunięto oskarżenia o kolaborację z rebeliantami Interahamwe. W sumie aresztowano wtedy sto tysięcy ludzi, wiele księży i zakonnic. Symbolem kolaboracji stał się biskup Augustin Misago z diecezji Gikongoro (Diocese of Gikongoro, 2021). Oskarżono go o inspirowanie do ludobójstwa - powodem takich oskarżeń był udział np. w gremium zbliżonym ze środowiskiem ówczesnej władzy. W skomplikowanej rzeczywistości po $1994 \mathrm{r}$. Kościół rzymskokatolicki w 1997 r. uznał grzechy pojedynczych swoich członków, w tym duchownych, jednak konsekwentnie zaprzeczał swojej ,odpowiedzialności instytucjonalnej" (Carney 2014, 218). Bezprecendensowym pomysłem na symboliczne zakończenie ery po ludobójstwie była propozycja księdza Henryka Hosera SAC, ówczesnego przedstawiciela Stolicy Apostolskiej w Rwandzie, w miejsce nuncjusza: „Po wojnie to był szok. Zaproponowałem (biskupom) aby zawiesić (na trzy miesiące) życie sakramentalne $\mathrm{w}$ ramach ekspiacji, aby był post eucharystyczny. Chciałem cezury, odcięcia się od tego co było. Biskupi się nie zgodzili na to, było parcie na szybki powrót do normalności” (Hoser 2020, 3-4).

Patrząc na propozycję księdza Henryka Hosera SAC, aby dokonać symbolicznego otwarcia w okresie po ludobójstwie, należy docenić jej śmiałość i odwagę, które by pozwoliły duchowieństwu przeżyć ten czas w duchu pokuty i pojednania.

W 2017 r. papież Franciszek wyprzedził działania biskupów rwandyjskich, gdy podczas audiencji dla prezydenta Paula Kagame ,poprosił o przebaczenie za grzechy i wady Kościoła w 1994 roku" (Fried 2017). Ten papieski gest wywołał sporą konsternację pośród rwandyjskiego episkopatu. Biskupom jednak nie wypadało krytykować swojego przełożonego, a ten ostatni gest na drodze uznania win lokalnego Kościoła stał się faktem na najwyższym kościelnym szczeblu.

\section{Próba oceny postaw duchowieństwa w czasie ludobójstwa 1994 roku}

Podsumowując postawy duchowieństwa rzymskokatolickiego podczas ludobójstwa w 1994 r., należy stwierdzić, że były one zróżnicowane przede wszystkim pod względem pochodzenia etnicznego. Duchowni wywodzący się z plemion bądź Hutu, bądź Tutsi, często przejawiali sympatię ze swoimi plemiennymi pobratymcami. W jednostkowych przypadkach przynależność do plemienia Hutu stała się powodem do współudziału w ludobójstwie i wspierania bojówek Interahamwe. Jednak były to zjawiska jednostkowe i odosobnione. Pojawiły się także postawy inspirowane imperatywem wiary chrześcijańskiej - okazanie pomocy potrzebującym i prześladowanym. Od pomocy niesionej w ukryciu pod osłoną 
nocy, aż po oddanie życia ze swoimi podopiecznymi - przykład siostry Felicite z plemienia Hutu. W obecnej sytuacji trudno określić, jak wielu duchownych spośród liczby od 200 do 250 poniosło śmierć o charakterze męczeńskim. Pojedyncze świadectwa wskazują na to, że mogło tych ludzi być całkiem dużo. Jednak by to jednoznacznie ocenić, należy dokonać szczegółowych badań nad okolicznościami śmierci każdego duchownego i zakonnicy. W obecnej sytuacji społeczno-politycznej w Rwandzie, gdzie dominuje jednostronna narracja o ludobójstwie dokonanym przez plemię Hutu na plemieniu Tutsi, jest to dosyć utrudnione, aby zbierać szczegółowe informacje o duchownych męczennikach. W Rwandzie powszechnie wiadomo, że po stu dniach ludobójstwa nastąpiła reakcja RPF, to znaczy odwet na dawnych bojówkach Interahamwe. Wielu z tych ludzi uciekło do ościennych państw i już nie wróciło do Rwandy. Szacuje się, że po obaleniu rządu Hutu w 1994 r. około 2000000 członków plemienia Hutu uciekło do sąsiednich państw. Obecnie obawiają się wrócić, gdyż sądzą, że nie będzie im zapewniony sprawiedliwy proces. Dlatego też zbieranie informacji o duchownych pochodzących z plemienia Hutu, którzy oddawali swoje życie w obronie prześladowanych z plemienia Tutsi, nie jest aktualnie łatwym zadaniem w Rwandzie. Przykładem może tutaj być tragiczna historia rwandyjskiego piosenkarza Kizito Mihigo, który został uwięziony po publicznym zaśpiewaniu słów: „dlaczego nie wolno mi opłakiwać moich bliskich". Podczas swojego pobytu w więzieniu miał popełnić samobójstwo przez powieszenie. Kizito Mihigo pochodził z plemienia Hutu.

\section{Zakończenie}

Opisując przykłady zachowań duchowieństwa rzymskokatolickiego podczas stu dni ludobójstwa w 1994 r., nie wyczerpuje się w pełni tego zagadnienia. Jest to raczej wycinkowe pokazanie skomplikowanej rzeczywistości społeczeństwa w Rwandzie, którego częścią jest Kościół rzymskokatolicki i jego duchowni. Mimo wyraźnych dowodów na to, że znacznie większa część duchowieństwa oddała swoje życie w obronie prześladowanych, Kościół jest najczęściej oskarżany o kolaborację z rebeliantami Hutu. Pokazuje to, jak trudno w przestrzeni medialnej przebić się z prawdą, iż było znacznie więcej duchownych, którzy zachowali się w heroiczny sposób niż tych, którzy kolaborowali z rebeliantami.

Inną kategorią duchownych, którą też należy wyraźnie pokazać, to misjonarze, którzy mimo woli stali się świadkami ludobójstwa - część z nich wyjechała z Rwandy i już do niej nie wróciła. Jednak nie ma żadnego świadectwa, które by mówiło o tym, że misjonarze brali czynny udział w ludobójstwie na przedstawicielach plemienia Tutsi w 1994 r. w Rwandzie.

Pośród nietypowych zachowań duchownych warto przytoczyć przykład księdza Wenceslasa Munyenshayaka, który w czasie ludobójstwa publicznie pokazy- 
wał się w kamizelce kuloodpornej i z bronią palną: „Po trzech dniach do kościoła dotarli Interahamwe, czyli bojówkarze Hutu. Doszło do masakry. Ks. Munyeshyaka przeżył, ale nawet po zakończeniu 100-dniowego ludobójstwa obawiał się o swoje życie. Hutu mogli go zabić za pomoc Tutsim, a Tutsi - za pochodzenie. Kiedy miejscowa prasa wszczęła przeciw niemu oszczerczą kampanię, zbiegł do Zairu. Będąc tam wspólnie $\mathrm{z}$ wieloma innymi duchownymi, podpisał list do Jana Pawła II. W piśmie podkreślano, że nie tylko bojówki Hutu, ale i siły RPF popełniają zbrodnie. List ten do dziś pokazywany jest jako dowód na to, że duchowny popierał morderców z Hutu. W 1995 r. ks. Munyeshyaka został przez władze w Kigali wciągnięty na listę winnych ludobójstwa. Dzięki pomocy Zakonu Braci Białych trafił do Francji, gdzie do dziś posługuje" (Jałowiczor 2018).

Niewątpliwie fakt noszenia broni palnej przez kapłana rzymskokatolickiego jest czymś zaskakującym a nawet szokującym w czasie pokoju. Czy można tę miarę przyłożyć do czasu bestialskiego ludobójstwa? Ostatecznie, każdy człowiek chce przeżyć wojnę i żyć w pokoju.

Osobnym problemem badawczym jest zjawisko motywacji duchownych, którzy zdecydowali się przyłączyć do rebeliantów Hutu. Prawdopodobnie nie jest już to możliwe, aby poznać ich motywację - pozostają tylko świadkowie, którzy słuchali ich kazań i innych publicznych wypowiedzi. Być może ci ludzie kiedyś zdecydują się opowiedzieć o tym, co ci duchowni w tamtym czasie mówili. Jednak to najczęściej ludzkie czyny zostają najbardziej zapamiętane i najmocniej przemawiają do następnych pokoleń. Nawet jeśli te czyny są zbrodnicze, to mogą i powinny być memento dla następnych pokoleń, jak nie należy postępować wobec mniejszości etnicznych. 


\section{THE ROLE OF THE CLERGY OF THE ROMAN CATHOLIC CHURCH DURING THE RWANDAN GENOCIDE IN 1994. A LOOK FROM THE PERSPECTIVE OF 27 YEARS AFTER THE EVENTS}

\section{SUMMARY}

During the Rwandan genocide in 1994, the clergy of the Roman Catholic Church played a specific role. The dominant view in the general public opinion is that these clergy either passively or actively supported the genocide committed by the Hutu tribe against the Tutsi tribe. The reality, however, is more complicated. While there were about 20 collaborating clergymen, over 200 clerics died as a result of genocide. This article aims to show how complicated and ambiguous the situation of the clergy was during the real threat of death in 1994.

Keywords: Church, genocide, priest, clergyman, Rwanda 1994

Słowa kluczowe: Kościół, ludobójstwo, ksiądz, duchowny, Rwanda 1994

\section{BIBLIOGRAFIA}

\section{Źródła drukowane}

Bar, Joanna. 2013. Po ludobójstwie. Państwo i spoleczeństwo w Rwandzie 1994-2012, Kraków: Księgarnia Akademicka.

Carney, J.J. 2014. Rwanda before the Genocide. Catholic politics and ethic discourse in the late colonial era, Oxford: University Press.

d'Amour Dusengumuremyi, Jean. 2015. No Greater Love. Testimonies on the Life and Death of Felicitas Niyitegeka, Lake Oswego.

Hoser, Henryk Franciszek i Michał Królikowski. 2013. Bóg jest większy, Ząbki: Wydawnictwo Apostolicum.

Jaworski, Maciej. 2020. Niezwykła historia zwyczajnej posługi. 50 lat misji Karmelitów w Burundi i Rwandzie, Kraków: Wydawnictwo Karmelitańskie.

Reginia-Zacharski, Jacek. 2012. Rwanda wojna i ludobójstwo, Warszawa: Wydawnictwo Naukowe PWN.

Tochman, Wojciech. 2010. Dzisiaj narysujemy śmierć, Wołowiec: Wydawnictwo Czarne.

\section{Spisane świadectwo}

Hoser, Henryk. 2020. rozmowa autora z dnia 20 stycznia 2020, archiwum prywatne autora. 3-4.

\section{Źródla internetowe}

Diocese of Gikongoro. 2021. Dostęp: 16.12.2021. https://www.catholic-hierarchy.org/diocese/dgiko.html

Diocese of Kabgayi. 2021. Dostęp: 16.12.2021. https://www.catholic-hierarchy.org/diocese/dkabg. html

Fried, Brittany. 2017. Catholic perpetration and reconcilitation in Rwanda. Dostęp: 16.12.2021. https://berkleycenter.georgetown.edu/posts/catholic-perpetration-and-reconciliation-in-rwanda 
Jałowiczor, Jakub. 2018. Oskarżeni o ludobójstwo. Dostęp: 16.12.2021. https://kosciol.wiara.pl/ doc/4902138. Oskarzeni-o-ludobojstwo

„Konrad jest w Rwandzie”. Blog internetowy. 2009. Dostęp: 16.12.2021. https://konradjestwrwandzie.wordpress.com/2008/10/10/ksieza-w-czasach-ludobojstwa/

Rwanda Convention Bureau. About Huye. 2021. Dostęp: 16.12.2021. https://rcb.rw/-HUYE-.html

Dawid Stelmach - kapłan, doktor, ur. 1978 r. w Poznaniu, święcenia kapłańskie 2005 r. w Poznaniu, doktorat na Uniwersytecie im. Adama Mickiewicza w Poznaniu w 2014 r., adiunkt w Zakładzie Teologii Systematycznej. Zainteresowanie naukowe: problematyka pojednania w Rwandzie po 1994 r. i wzajemne oddziaływania chrześcijaństwa i popkultury. 